\title{
Broth medium for the successful culture of the fish pathogen Piscirickettsia salmonis
}

\author{
A. J. Yañez ${ }^{1, *}$, K. Valenzuela ${ }^{1}$, H. Silva ${ }^{1}$, J. Retamales ${ }^{2}$, A. Romero ${ }^{3}$, R. Enriquez ${ }^{3}$, \\ J. Figueroa ${ }^{1}$, A. Claude ${ }^{1}$, J. Gonzalez ${ }^{4}$, R. Avendaño-Herrera ${ }^{2}$, J. G. Carcamo ${ }^{1}$ \\ ${ }^{1}$ Laboratorio de Enzimología, Instituto de Bioquímica, and ${ }^{3}$ Instituto de Patología, \\ Facultad de Ciencias, Universidad Austral de Chile, Valdivia, Chile \\ ${ }^{2}$ Laboratorio de Patología de Organismos Acuáticos y Biotecnología Acuícola, Facultad de Ciencias Biológicas, \\ Universidad Andrés Bello, Viña del Mar, Chile \\ ${ }^{4}$ EWOS Chile Alimentos Ltda, Coronel, Chile
}

\begin{abstract}
Piscirickettsiosis or salmonid rickettsial septicaemia (SRS) caused by Piscirickettsia salmonis constitutes one of the main problems in farmed salmonid and marine fishes. Since the first reports of the disease, it has been successfully isolated and maintained in eukaryotic cellculture systems, but these systems are time-consuming, the media are costly, and eliminating heavily contaminated host cell debris is difficult. In this report, we describe a marine-based broth supplemented with L-cysteine, named AUSTRAL-SRS broth, that facilitates superior growth of $P$. salmonis strains. Strains reached an optical density of approximately 1.8 when absorbance was measured at $600 \mathrm{~nm}$ after $6 \mathrm{~d}$ incubation at $18^{\circ} \mathrm{C}$. Several passages $(\mathrm{n}=6)$ did not alter the culture kinetics. We report for the first time the purification of DNA, lipopolysaccharide (LPS) and whole membrane protein obtained from $P$. salmonis grown in this liquid medium, and thus provide a suitable platform to simplify the preparation of $P$. salmonis cells for genetic and serological studies. Moreover, the results of the cytopathic effect test showed that $P$. salmonis grown in AUSTRALSRS broth maintained their virulence properties, inducing apoptosis after $3 \mathrm{~d}$. This makes the medium a good candidate for the successful growth of $P$. salmonis and an excellent basis for the development of low cost vaccines.
\end{abstract}

KEY WORDS: Piscirickettsia salmonis $\cdot$ Broth $\cdot$ Culture

\section{INTRODUCTION}

Piscirickettsiosis or salmonid rickettsial septicaemia (SRS) caused by Piscirickettsia salmonis constitutes one of the main problems in farmed salmonid and marine fishes (see reviews by Almendras \& Fuentealba 1997, Mauel \& Miller 2002, Fryer \& Hedrick 2003). This fastidious pathogen was initially observed in southern Chile in 1989 (Bravo \& Campos 1989, Branson \& Diaz-Muñoz 1991, Cvitanich et al. 1991), followed by observations in western Canada (Brocklebank et al. 1992), Ireland (Rodger \& Drinan
1993), Scotland (Grant et al. 1996), Norway (Olsen et al. 1997), eastern Canada (Cusack et al. 2002) and southern California, USA (Arkush et al. 2005).

The disease is preliminarily diagnosed by the clinical signs of the affected fish, which usually show a systemic infection targeted to the kidney, liver, spleen, brain, intestine, ovary and gills of the fish (Cvitanich et al. 1991, Garcés et al. 1991). Normally, infected samples are subjected to microscopic and histological observation (Lannan \& Fryer 1991), but this diagnosis must be confirmed by the isolation of Piscirickettsia salmonis from tissues cultured within 
fish cell lines in vitro (Fryer et al. 1990), followed by immunohistochemistry, polymerase chain reaction on DNA extracted from infected tissues, or by subjecting cell-cultured bacteria to a specific fluorescent antibody test identification (OIE 2006). The use of agar media is an alternative that shows potential and would relieve facilities of the cost of maintaining cell lines as these are time-consuming and costly, and it would eliminate heavily contaminated host cell debris. The use of specific enriched sheep blood agar prepared with cysteine has been developed for the cultivation of P. salmonis strains (Mauel et al. 2008, Mikalsen et al. 2008). Growth on solid media usually takes from 4 to $6 \mathrm{~d}$ for visible colonies to appear, but these are often poorly defined, leading to inaccuracies in estimations of the bacterial concentration.

During the development of a solid medium, Mikalsen et al. (2008) employed cysteine heart broth, with or without $5 \%$ sheep blood, in order to study the growth of one Piscirickettsia salmonis isolate, but these authors did not detail the rates and overall levels of growth in broth. Here we describe a marine broth medium supplemented with L-cysteine, named AUSTRAL-SRS broth, that facilitates growth of $P$. salmonis strains. This broth should make it possible to culture strains needed to determine the minimum inhibitory concentration of drugs and to prepare cells for the development of low-cost vaccines for protection against piscirickettsiosis.

\section{MATERIALS AND METHODS}

\section{Bacterial strains}

Two Piscirickettsia salmonis isolates (PPT-05 and PPT-15) recovered in 2008 from diseased farmed rainbow trout Oncorhynchus mykiss in Chile were used to test the liquid culture media. The type strain $P$. salmonis ATCC VR-1361 (equivalent to LF-89) originally obtained from coho salmon $O$. kisutch was included for comparative purposes and was obtained from the American Type Culture Collection (ATCC). All bacterial strains were confirmed as $P$. salmonis using PCR-based analysis described by Marshall et al. (1998) and also by an indirect fluorescent antibody test (IFAT, SRS-BiosChile) according to the manufacturer's recommendation. For growth on solid media, bacteria were streaked onto tryptone soy supplemented with ferric nitrate (AUSTRAL-TSFe) agar plates and incubated at $18^{\circ} \mathrm{C}$ for $10 \mathrm{~d}$. Stock cultures were prepared from cells scraped off TSFe plates and resuspended in $1 \mathrm{ml}$ of L-15 Leibovitz medium con- taining $20 \%$ fetal bovine serum (AUSTRAL-FBS) and $10 \%$ dimethyl sulphoxide (DMSO) and stored frozen at $-80^{\circ} \mathrm{C}$ or in Criobille tubes (AES Lab).

\section{Liquid culture medium}

Initially, 110 different formulations were tested to evaluate the efficacy of growing the Piscirickettsia salmonis type strain. In these different media, formulations with several concentrations/combinations of marine broth, sodium chloride, triptone soy, Yeastolate, L-cysteine, ferric salt and hemoglobin were tested. Marine broth was obtained from Becton, Dickinson and Company, L-cysteine and Yeastolate from USBiological, and ferric nitrate from Merck. Only 2 formulations facilitated growth of $P$. salmonis, ATCC VR-1361 being one of them and AUSTRALSRS broth, which was the best medium. The composition and preparation of the AUSTRAL-SRS broth is presented in Appendix 1. To determine the optimal concentration of the 3 components, an independent study with each component was preliminary tested using L-cysteine concentrations of 1 to $50 \mathrm{~g} \mathrm{l}^{-1}$, and between 0.001 and $1 \mathrm{mM}$ for ferric nitrate. The final $\mathrm{pH}$ of the medium was between 6.0 and 6.4 at room temperature. FBS is also a critical component and was added to a final concentration of $5 \% \mathrm{p} / \mathrm{v}$.

\section{Incorporation of Piscirickettsia salmonis into broth cultures}

Five colonies grown on AUSTRAL-TSFe plates were used to prepare the starting inocula of all Piscirickettsia salmonis isolates. Bacterial suspensions were prepared in sterile AUSTRAL-SRS broth, and $2 \mathrm{ml}$ aliquots were adjusted at 1.0 absorbance at $600 \mathrm{~nm}$ measured on a spectrophotometer. These aliquots were then inoculated into $100 \mathrm{ml}$ Erlenmeyer flasks containing $20 \mathrm{ml}$ culture medium, resulting in an initial bacterial concentration of $10^{8}$ cells $\mathrm{ml}^{-1}$ as determined by direct microscopy count (equivalent to $10^{7}$ colony-forming units [CFU] $\mathrm{ml}^{-1}$ ). Control cultures were run simultaneously without the addition of bacteria. Incubation was carried out for $10 \mathrm{~d}$ at a controlled temperature of $18^{\circ} \mathrm{C}$, with or without moderate agitation (50 rpm). The light regime used was $0 \mathrm{~h}$ light: $24 \mathrm{~h}$ dark. The experiment was carried out in triplicate for each bacterial strain.

In order to examine whether Piscirickettsia salmonis can suffer a reduction in growth, a P. salmonis type strain was subjected to 6 serial passages using 
as inocula for each passage $2 \mathrm{ml}$ aliquots obtained from the preceding bacterial culture after $6 \mathrm{~d}$ of incubation.

\section{Evaluation of bacterial growth curves}

To determine the growth of the Piscirickettsia salmonis strains, absorbance at $600 \mathrm{~nm}$ was recorded every $24 \mathrm{~h}$, and at the same time the evolution of culturable cells in each flask was carried out by seeding serial diluted samples in L-15 medium with $10 \%$ FBS and placing them on AUSTRAL-TSFe agar plates followed by incubation at $18^{\circ} \mathrm{C}$ for $10 \mathrm{~d}$. All plating was done in duplicate, and the number of viable bacterial cells in the broth culture was calculated from the dilution that yielded between 30 and 300 colonies on the agar plates.

\section{Identification of Piscirickettsia salmonis by PCR}

Samples (1 ml) from each broth culture were taken daily during the first week and colonies were collected and placed in $1.5 \mathrm{ml}$ sterile tubes, which were then centrifuged at $12000 \times g$ for $5 \mathrm{~min}$. Extraction of DNA from bacterial pellets was performed using InstaGene Matrix (Bio-Rad) according to the manufacturer's instructions. The concentration of each DNA sample was adjusted to 10 to

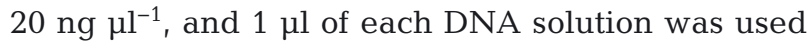
in each amplification reaction. To confirm their designation as $P$. salmonis, all strains were tested using the primer pair RT1-RTS2 designed by Marshall et al. (1998). The amplification cycles used for denaturation, primer annealing and extension were carried out according to a published PCR protocol (Marshall et al. 1998). A positive result was indicated by the presence of an amplification product of $91 \mathrm{bp}$ after electrophoresis through a $1.5 \%(\mathrm{w} / \mathrm{v})$ agarose gel. All analyses were carried out with DNA obtained in 2 different extractions.

\section{Analysis of cellular changes and surface components}

To determine whether Piscirickettsia salmonis suffered cellular changes during the experimental period, samples of bacterial culture were visualised every day by light microscopy. Moreover, we analyzed the lipopolysaccharide (LPS) and membrane protein profiles due to possible changes in the com- ponent of the bacterial cell wall. LPSs from the cell envelopes were obtained by the Proteinase K (PK) method following the procedures of Hitchcock \& Brown (1983). Samples were examined by sodium dodecyl sulphate-polyacrylamide gel electrophoresis (SDS-PAGE; Laemmli 1970), with $14 \%$ (w/v) acrylamide in the resolving gel and $4 \%$ (w/v) acrylamide in the stacking gel, and then silver stained following the procedure of Tsai \& Frasch (1982). The whole cell envelope proteins from the $P$. salmonis strains were prepared from bacterial culture grown in AUSTRALSRS broth as described by Pot et al. (1994) and examined by SDS-PAGE with $12 \%$ (w/v) acrylamide in the resolving gel and $4 \%$ (w/v) acrylamide in the stacking gel. Protein bands were stained with 0.05\% Coomassie Brilliant Blue R (Sigma), photographed, and the relative mobilities of each were determined by comparison with standard protein markers.

\section{Evaluating Piscirickettsia salmonis infectivity in vitro}

The invasion assays were performed in salmon head kidney (SHK-1) cells cultured at $18^{\circ} \mathrm{C}$ in 24 -well tissue culture plates. A concentration of $1 \times 10^{5}$ SHK 1 cells was inoculated into each well and grown in Leibovitz's L-15 medium supplemented with 10\% SFB, $6 \mathrm{mM}$ L-glutamine (Hyclone Laboratories) and $40 \mu \mathrm{M} 2$-mercaptoethanol (Gibco, Invitrogen Laboratories). One day after incubation, $1000 \mu \mathrm{l}$ of P. salmonis suspension prepared in L-15 medium with $2 \%$ FBS $\left(1 \times 10^{6}\right.$ cells well $\left.{ }^{-1}\right)$ were inoculated into each well containing the cell monolayers and incubated at $18^{\circ} \mathrm{C}$ for $9 \mathrm{~d}$. Control cell cultures were run simultaneously without the addition of bacteria.

Possible differences in the permeability of the membrane in SHK-1 cells exposed to the Piscirickettsia salmonis were determined by evaluating the liberation level of the cytosolic enzyme lactate dehydrogenase $(\mathrm{LDH})$ in the cell supernatant using the commercial LDH-P UV Assay (Wiener Lab) kit. In brief, samples of $1 \mathrm{ml}$ of cell culture, taken daily, were centrifuged at $1600 \mathrm{rpm}(176 \times g)$ for $5 \mathrm{~min}$, and the LDH liberation level in $20 \mu$ l of supernatant was obtained in accordance with the supplier's instructions. Absorbance at $340 \mathrm{~nm}$ was read after $30,60,120$ and $180 \mathrm{~s}$ from the first reading. The average difference of the absorbance $\left(\Delta A \mathrm{~min}^{-1}\right)$ was determined by subtracting each absorbance value from 2 replicates and averaging the LDH. The result was obtained using the equation: LDH $\left(\mathrm{IU}{ }^{-1}\right)=\Delta A \mathrm{~min}^{-1} \times$ factor $(8.095)$. 
In addition, the morphology of the fish cell line was examined using a phase-contrast inverted microscope at 400 or $600 \times$ magnification.

\section{Statistical analyses}

The results were subjected to an analysis of variance (ANOVA; Sokal \& Rohlf 1980) in order to compare growth among treatments with or without agitation and in control culture. An alpha value of $p<0.05$ was used for all analysis.

\section{RESULTS AND DISCUSSION}

Before the liquid medium was used to culture all Piscirickettsia salmonis, a total of 110 specific marine or triptone soy broth formulations were screened by inoculating the $P$. salmonis type strain directly into each liquid medium. Only 2 of the 110 formulations tested showed growth at different levels, and the medium named AUSTRAL-SRS broth generated the better growth compared to the other media (Fig. 1), while the remaining 108 formulations did not support the growth of this strain.

In each medium, the Piscirickettsia salmonis type strain was identified by PCR analysis and IFAT tests and confirmed by partial 16S rRNA gene sequencing (data not shown). AUSTRAL-SRS broth was selected as ideal candidate for further studies. According to the criteria described by McGann et al. (2010), a liquid medium must induce rapid, high-density bacterial growth as measured by optical density (OD) at $600 \mathrm{~nm}$ and promote the efficient growth of low bacterial inocula.

When the growth curves of all Piscirickettsia salmonis were determined by measuring absorbance, the 3 strains grew well with and without moderate agitation (Fig. 2A). However, statistical analysis revealed a significant difference $(p<0.05)$ in the growth of all $P$. salmonis that were dependent on the movement of the broth culture. Maximum cell density was obtained with agitation (50 rpm), with $64.7 \%$ more than the density obtained in the static Erlenmeyer flasks after $6 \mathrm{~d}$ of incubation. In fact, the growth of $P$. salmonis with gentle shaking was characterised by a short lag phase (approximately $18 \mathrm{~h}$ ) followed by rapid logarithmic growth, achieving a maximal OD of approximately 1.8 after $6 \mathrm{~d}$ of incubation. From this point on, growth remained nearly constant during the experimental period (10 d) at OD values of approximately 1.68 .

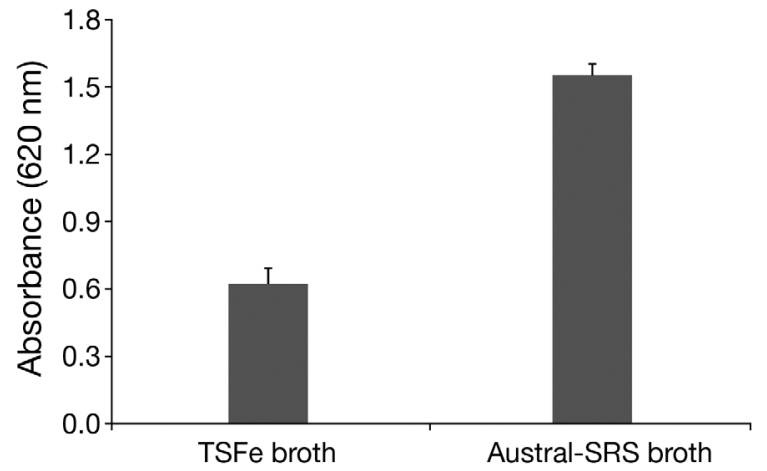

Fig. 1. Piscirickettsia salmonis. Comparison of the growth $( \pm \mathrm{SD})$ of the type strain in 2 of the 110 specific marine or triptone soy broth formulations tested in this study. TSFe broth: tryptone soy supplemented with ferric nitrate. Growth tests performed with $P$. salmonis on the remaining 108 media did not support the growth of the type strain after $10 \mathrm{~d}$ of incubation at $18^{\circ} \mathrm{C}$

It is important to point out that no difference was observed in the growth dynamics between the 2 Piscirickettsia salmonis isolates and the type strain, regardless of the number of replicates and the agitation condition, suggesting that in AUSTRAL-SRS
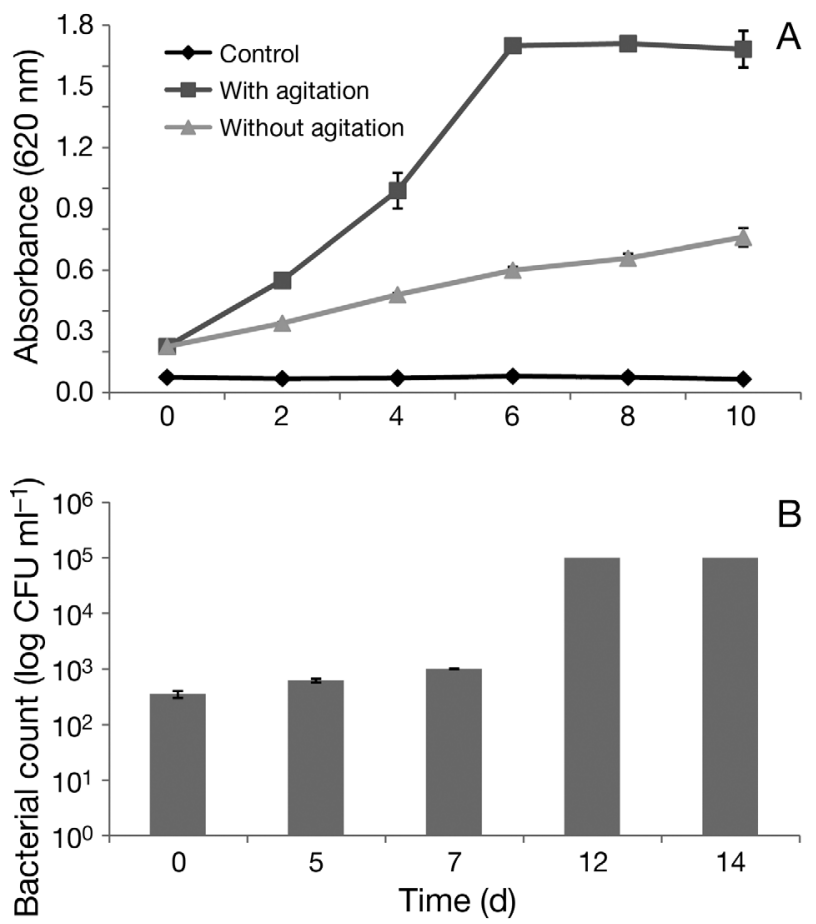

Fig. 2. Piscirickettsia salmonis. (A) Average growth of all strains used in this study in AUSTRAL-SRS broth with or without agitation and (B) the concentration of viable bacteria reached with agitation. The control was a liquid culture without the addition of bacteria. CFU: colony-forming unit. Vertical lines show \pm SD 
broth, the behaviour of this bacterium is reproducible. In fact, when a serial passage experiment was carried out, the $P$. salmonis type strain displayed similar growth kinetics, regardless of the number of passages, reaching absorbance values between 1.7 and 1.8 (data not shown).

Although the Piscirickettsia salmonis strain grew on AUSTRAL-TSFe agar, poorly defined colonies were produced, leading to inaccuracies in estimations of the CFU concentration. Thus, the bacterial count showed that the number of culturable bacteria during the first $5 \mathrm{~d}$ decreased by 4 log-units from an initial inoculum of $10^{7} \mathrm{CFU} \mathrm{ml}^{-1}$ (equivalent to $10^{8}$ cells $\mathrm{ml}^{-1}$ ). After this period, the number of culturable bacteria increased $2 \log$ units of $\mathrm{CFU} \mathrm{m} \mathrm{m}^{-1}$ at the end of the experiment, allowing the detection of $10^{5} \mathrm{P}$. salmonis CFU ml ${ }^{-1}$ (Fig. 2B).

Given that the persistence of culturable cells was lower than expected in correlation to absorbance values, we applied quantitative real-time PCR (qRTPCR) designed by Karatas et al. (2008) (data not shown). A slight increase in the number of Piscirickettsia salmonis cells from the initial inoculum was determined during the first $6 \mathrm{~d}$ (data not shown). Then, $12 \mathrm{~d}$ after the beginning of the experiment, the qRT-PCR count showed that the number of bacteria increased by $1 \log$ unit, reaching $7.3 \times 10^{9}$ cells. Therefore, $P$. salmonis lost its ability to grow on solid media, but retained viability in liquid media.

Despite the fact that the Piscirickettsia salmonis strains grew on specific enriched sheep blood agar prepared with cysteine (Mauel et al. 2008, Mikalsen et al. 2008) as well as in the blood-free medium employed in this work, the efficiency of recovering $P$. salmonis from all media is not suitable for determing the concentration of the bacterium, mainly because bacterial growth is extremely slow. In fact, growth on solid media usually takes from 4 to $8 \mathrm{~d}$ for visible colonies to appear (Mauel et al. 2008, Mikalsen et al. 2008). This disadvantage leads us to express the growth of $P$. salmonis in absorbance units or cells.

Microscopic observations under phase contrast of Piscirickettsia salmonis cultured into AUSTRAL-SRS broth did not reveal changes in the morphology and size of the bacteria, which appeared as Gram-negative cocci. An aliquot of each culture was observed under an epifluorescence microscope every day in order to confirm the presence of $P$. salmonis when exposed to a commercial rabbit fluorescein isothiocyanate (FITC)-conjugated anti-P. salmonis antibody. A strong and positive specific reaction was shown. As expected, liquid culture without the addition of $P$. salmonis did not yield any growth.
The result of the LPS profiling showed that all Chilean Piscirickettsia salmonis isolates and the type strain displayed a similar LPS pattern with a ladder of low molecular weight (LMW) O-antigen bands, but less abundant high molecular weight (HMW) species were present (Fig. 3A), matching the typical profile of the P. salmonis species reported by Kuzyk et al. (1996). These authors noted that silver staining of PKdigested $P$. salmonis revealed a ladder-like banding pattern of carbohydrates ranging from 16 to $35 \mathrm{kDa}$ in size with a discrete band around $20 \mathrm{kDa}$ and an intensely stained major band around $11 \mathrm{kDa}$. It is important to note that Kuzyk et al. (1996), using rabbit polyclonal antibodies, recognized this band as an $11 \mathrm{kDa}$ carbohydrate antigen corresponding to a lipooligosaccharide component of LPS, which was confirmed by other studies (Barnes et al. 1998, Jamett et al. 2001).

With regard to the analysis of whole cell envelope proteins, all Chilean Piscirickettsia salmonis strains presented a similar profile, displaying a considerable number of common bands between 116 and $25 \mathrm{kDa}$ (Fig. 3B). Similar results were reported by Barnes et al. (1998), who noted that $P$. salmonis studied contained a large, apparently similar protein, with 5 major protein bands with molecular masses of 30,42, 58, 70 and $105 \mathrm{kDa}$.

Adherence, invasion and intracellular replication in the host cells are important for pathogenesis by intracellular pathogens (Finlay \& Falkow 1997, Nobbs et al. 2009). It is well known that Piscirickettsia salmonis replicates by binary fission within membrane-bound cytoplasmic vacuoles in cells of susceptible fish hosts or fish cell lines inducing a characteristic cytopathic effect (CPE; Fryer \& Hedrick 2003).

Many studies on Piscirickettsia salmonis consider that Chinook salmon embryo (CHSE-214) cells offer considerable advantages over other fish, insect and frog tissue culture cells. However, Birkbeck et al. (2004) showed that $P$. salmonis replicates in higher titers in an insect cell line than in the CHSE-214 cells that are normally used to culture the organism and that $P$. salmonis retains virulence for Atlantic salmon Salmo salar after repeated culture in insect cells. On the other hand, the tissue chosen for the isolation of $P$. salmonis during active infection in salmonids is kidney, and SHK-1 is a cell line from $S$. salar head kidney, which exhibits macrophage properties (Dannevig et al. 1997).

Unpublished work in our laboratory has shown that Piscirickettsia salmonis strains produced CPE in CHSE-214 cells similar to that of SHK-1 cells, 


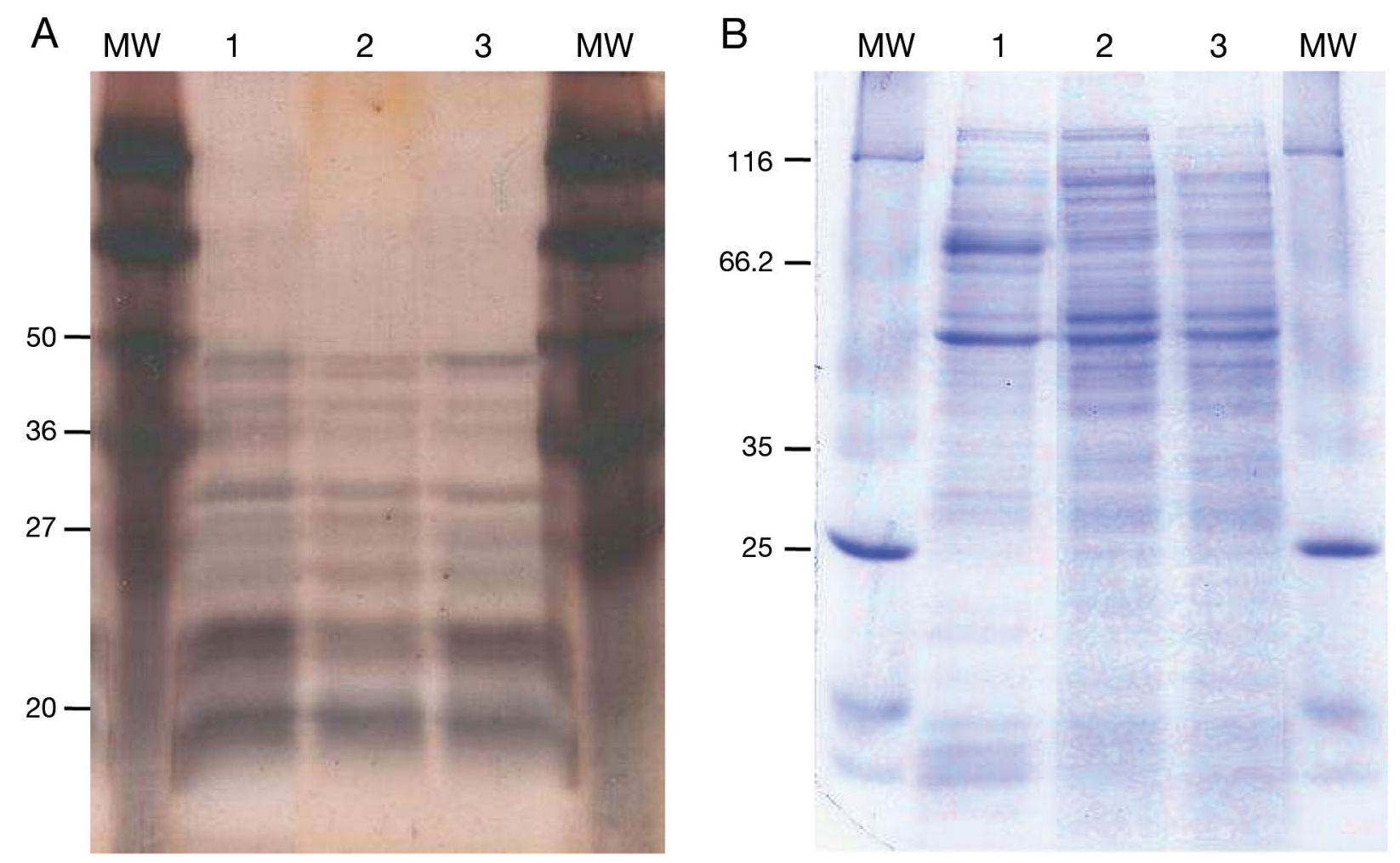

Fig. 3. Piscirickettsia salmonis. Sodium dodecyl sulphate-polyacrylamide gel electrophoresis (SDS-PAGE) of (A) silver-stains of lipopolysaccharides and (B) Coomassie stains of whole cell envelope proteins from Chilean isolates and the type strain cultivated in AUSTRAL-SRS broth. Lanes: MW, molecular weight markers; 1 , the type strain LF-89 ${ }^{\mathrm{T}} ; 2$ and 3, the Chilean isolates PPT-005 and PPT-0015, respectively. Numbers on the left indicate the positions of MWs (kDa)

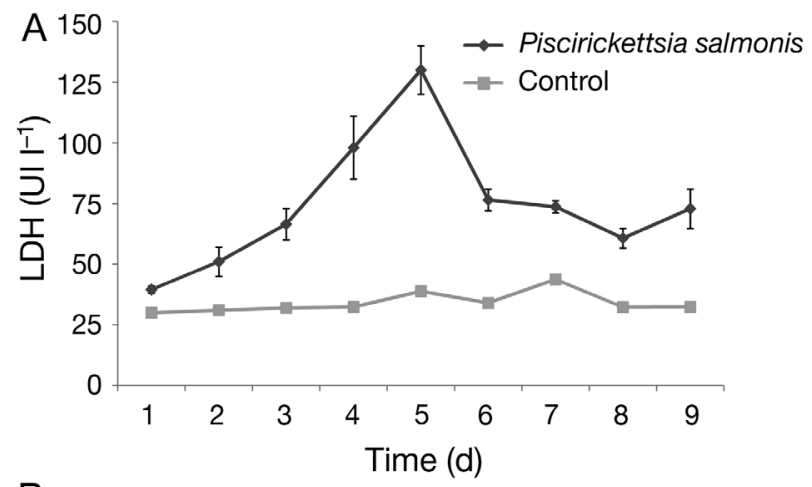

Fig. 4. (A) Lactate dehydrogenase (LDH) liberation (mean \pm SD) in salmon head kidney (SHK-1) cells infected with Piscirickettsia salmonis and control (non-infected) cells over 9 d. (B) The cytopathic effect on SHK-1 cells incubated with $P$. salmonis for 2, 5 and $8 \mathrm{~d}$. No structural changes were detected in SHK-1 cells without $P$. salmonis (control) (data not shown)
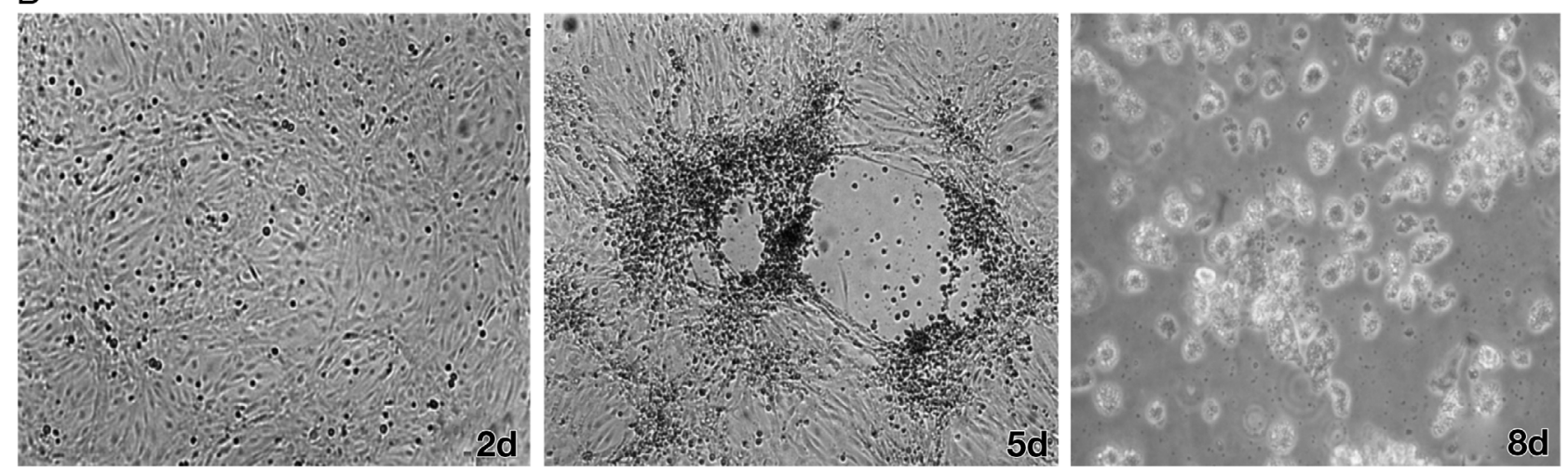
although the cell sheet was completely lysed $15 \mathrm{~d}$ post infection. Therefore, we decided to evaluate the effect of $P$. salmonis cells cultured in AUSTRAL-SRS broth into the SHK-1 cell line. Microscopic analysis revealed infectivity patterns similar to those reported by Olavarría et al. (2010), who observed the CPE after $3 \mathrm{~d}$ post infection, and due to their growth conditions, the infection spread to neighboring cells with total degenerative changes occurring in the SHK-1 cell line after $5 \mathrm{~d}$ of incubation (Fig. 4B).

In addition, the CPE was accompanied by a significant increase in the level of LDH liberation in SHK-1 cells inoculated with Piscirickettsia salmonis from Day 2 to Day 5 of the study, when $P$. salmonis showed the greatest level of liberation owing to greater damage of the cell membrane (Fig. 4A). After this, LDH analyses showed that the values declined very rapidly during the first $24 \mathrm{~h}$, followed by a stabilization around $70 \mathrm{LDH} \mathrm{IU} \mathrm{l}^{-1}$ until the end of the experiment.

As expected for the monolayers not inoculated with Piscirickettsia salmonis isolates, negative results of the CPE test and LDH analysis were found. Further confirmation of the identity of $P$. salmonis isolates was made using the IFAT test.

Our results suggest that, in addition to having the capacity to establish the infectious cycle and overcome cell barriers, this bacterium may also have a greater replication index and consequently be able to liberate cells with an infective capacity similar to that of other fish pathogens (Ortega et al. 2011). Therefore, the culture of the bacteria in broth medium does not affect the infective properties under in vitro conditions, but challenge experiments with fish are necessary to confirm that the Chilean isolates do cause the observed disease and fulfill Koch's postulates. Further studies are being done to confirm this hypothesis.

In conclusion, from a microbiological point of view, one of the major constraints on studies of Piscirickettsia salmonis is the ability to isolate different structural components (i.e. DNA, LPS and proteins) free of the host cell. We report for the first time the purification of DNA, LPS and membrane protein obtained from $P$. salmonis grown in a liquid medium, providing a suitable platform to simplify the preparation of $P$. salmonis cells for genetic and serological studies. Moreover, the results of the CPE test showed that $P$. salmonis grown in AUSTRAL-SRS broth maintain virulence and proteome properties, making this medium an excellent candidate for successful $P$. salmonis growth and a first-rate material for the development of low-cost vaccines as well as for monitoring antibiotic resistance.
Acknowledgements. Funding for this study was provided in part by Grant INNOVA CHILE 07CN13PPT-256, DID UACh S36-2008 from the Dirección de Investigación y Desarrollo de la Universidad Austral de Chile and also by Grant DI-0110/R from the Universidad Andres Bello. Thanks to M. V. M. Godoy for participation in the initiation of this study.

\section{LITERATURE CITED}

Almendras FE, Fuentealba IC (1997) Salmonid rickettsial septicemia caused by Piscirickettsia salmonis: a review. Dis Aquat Org 29:137-144

Arkush KD, McBride AM, Mendonca HL, Okihiro MS and others (2005) Genetic characterization and experimental pathogenesis of Piscirickettsia salmonis isolated from white seabass Atractoscion nobilis. Dis Aquat Org 63: 139-149

Barnes MN, Landolt ML, Powell DB, Winton JR (1998) Purification of Piscirickettsia salmonis and partial characterization of antigens. Dis Aquat Org 33:33-41

Birkbeck TH, Griffen AA, Reid HI, Laidler LA, Wadsworth S (2004) Growth of Piscirickettsia salmonis to high titers in insect tissue culture cells. Infect Immun 72:3693-3694

Branson EJ, Diaz-Muñoz DN (1991) Description of a new disease condition occurring in farmed coho salmon, Oncorhynchus kisutch (Walbaum), in South America. J Fish Dis 14:147-156

Bravo S, Campos M (1989) Coho salmon syndrome in Chile. Am Fish Soc Fish Health Sect Newsl 17:3

Brocklebank JR, Speare DJ, Armstrong RD, Evelyn T (1992) British Columbia septicemia suspected to be caused by a rickettsia-like agent in farmed Atlantic salmon. Can Vet J 33:407-408

Cusack RR, Groman DB, Jones SRM (2002) Rickettsial infection in farmed Atlantic salmon in eastern Canada. Can Vet J 43:435-440

> Cvitanich JD, Garate O, Smith CE (1991) The isolation of a rickettsia-like organism causing disease and mortality in Chilean salmonids and its confirmation by Koch's postulate. J Fish Dis 14:121-145

> Dannevig BH, Brudeseth BE, Gjoen T, Rode M, Wergeland HI, Evensen Ø (1997) Characterisation of a long-term cell line (SHK-1) developed from the head kidney of Atlantic salmon (Salmo salar). Fish Shellfish Immunol 7:213-226

> Finlay BB, Falkow S (1997) Common themes in microbial pathogenicity revisited. Microbiol Mol Biol Rev 61: 136-169

> Fryer JL, Hedrick RP (2003) Piscirickettsia salmonis: a Gram-negative intracellular bacterial pathogen of fish. J Fish Dis 26:251-262

> Fryer JL, Lannan CN, Garces LH, Larenas JJ, Smith PA (1990) Isolation of a rickettsiales-like organism from diseased coho salmon (Oncorhynchus kisutch) in Chile. Fish Pathol 25:107-114

> Garcés LH, Larenas JJ, Smith PA, Sandino S, Lannan CN, Fryer JL (1991) Infectivity of a rickettsia isolated from coho salmon Oncorhynchus kisutch. Dis Aquat Org 11: 93-97

Grant AN, Brown AG, Cox DI, Birkbeck TH, Griffen AA (1996) Rickettsia-like organism in farmed salmon. Vet Rec 138:423

Hitchcock PJ, Brown TM (1983) Morphological heterogeneity among Salmonella lipopolysaccharide chemotypes in silver-stained polyacrylamide gels. J Bacteriol 154: 269-277 
Jamett A, Aguayo J, Miquel A, Muller I and others (2001) Characteristics of monoclonal antibodies against Piscirickettsia salmonis. J Fish Dis 24:205-215

Karatas S, Mikalsen J, Steinum TM, Taksdal T, Bordevik M, Colquhoun DJ (2008) Real time PCR detection of Piscirickettsia salmonis from formalin-fixed paraffin-embedded tissues. J Fish Dis 31:747-753

Kuzyk MA, Thorton JC, Kay WW (1996) Antigenic characterization of the salmonid pathogen Piscirickettsia salmonis. Infect Immun 64:5205-5210

Laemmli UK (1970) Cleavage of structural proteins during the assembly of the head of bacteriophage T4. Nature 227:680-685

Lannan C, Fryer J (1991) Recommended methods for inspection of fish for the salmonid rickettsia. Bull Eur Assoc Fish Pathol 11:135-136

> Marshall S, Heath S, Henriquez V, Orrego C (1998) Minimally invasive detection of Piscirickettsia salmonis in cultivated salmonids via the PCR. Appl Environ Microbiol 64:3066-3069

Mauel MJ, Miller DL (2002) Piscirickettsiosis and piscirickettsiosis-like infections in fish: a review. Vet Microbiol 87:279-289

Mauel MJ, Ware C, Smith PA (2008) Culture of Piscirickettsia salmonis on enriched blood agar. J Vet Diagn Invest 20:213-214

McGann P, Rozak DA, Nikolich MP, Bowden RA, Lindler LE, Wolcott MJ, Lathigra R (2010) A novel brain heart infusion broth supports the study of common Francisella tularensis serotypes. J Microbiol Methods 80:164-171

Mikalsen J, Skjaervik O, Wiik-Nielsen J, Wasmuth MA, Colquhoun DJ (2008) Agar culture of Piscirickettsia salmonis, a serious pathogen of farmed salmonid and marine fish. FEMS Microbiol Lett 278:43-47
Nobbs AH, Lamont RJ, Jenkinson HF (2009) Streptococcus adherence and colonization. Microbiol Mol Biol Rev 73: 407-450

OIE (World Organisation for Animal Health) (2006) Manual of diagnostic tests for aquatic animals 2006. World Organisation for Animal Health, Paris

> Olavarría VH, Gallardo L, Figueroa JE, Mulero V (2010) Lipopolysaccharide primes the respiratory burst of Atlantic salmon SHK-1 cells through protein kinase Cmediated phosphorylation of p47phox. Dev Comp Immunol 34:1242-1253

Olsen AB, Melby HP, Speilberg L, Evensen O, Hastein T (1997) Piscirickettsia salmonis infection in Atlantic salmon Salmo salar in Norway - epidemiological, pathological and microbiological findings. Dis Aquat Org 31: $35-48$

> Ortega C, Rodríguez S, de Las Heras AI, Romero A, Monrás M, Enríquez R (2011) Evaluation of the level of Mx3 protein synthesis induced by infectious pancreatic necrosis virus (IPNV) strains of different infectivity. Vet Immunol Immunopathol 141:190-200

Pot B, Vandamme P, Kersters K (1994). Analysis of electrophoretic whole-organism protein fingerprints. In: Goodfellow M, O'Donnell AG (eds) Chemical methods in prokaryotic systematics. Wiley, Chichester, p 493-521

Rodger HD, Drinan EM (1993) Observation of a rickettsialike organism in Atlantic salmon Salmo salar L., in Ireland. J Fish Dis 16:361-369

Sokal R, Rohlf J (1980) Introducción a la bioestadística. De Reverte S.A., Barcelona

- Tsai CM, Frasch CE (1982) A sensitive silver stain for detecting lipopolysaccharides in polyacrylamide gels. Anal Biochem 119:115-119 
Appendix 1. AUSTRAL-SRS broth is a supplemented media for Piscirickettsia salmonis culture based on peptone and yeast extract as a source of nitrogen, vitamins and minerals. The high salt content helps to simulate seawater; numerous minerals are also included to duplicate the major mineral composition of seawater. Preparation for $1 \mathrm{l}$ : Dissolve ingredients 1 to $21 \mathrm{in} 900 \mathrm{ml}$ of distilled water and sterilize by autoclaving at $121^{\circ} \mathrm{C}$ for $15 \mathrm{~min}$. Allow media to cool at room temperature and aseptically add ingredients 22 to 50 . All ingredi ents except 50 are in $\mathrm{mg} \mathrm{l}^{-1}$. FBS: fetal bovine serum

\begin{tabular}{|c|c|c|}
\hline \multicolumn{2}{|c|}{ Component } & Amount $\left(\mathrm{mg} \mathrm{l}^{-1}\right)$ \\
\hline \multicolumn{3}{|c|}{ Inorganic salts } \\
\hline 1 & Ammonium nitrate & 0.2 \\
\hline 2 & Boric acid & 2.8 \\
\hline 3 & Calcium chloride $\left(\mathrm{CaCl}_{2}\right)$ (anhydride) & 246.1 \\
\hline 4 & Disodium phosphate & 1.0 \\
\hline 5 & Ferric citrate & 12.6 \\
\hline 6 & Feric nitrate & 5.0 \\
\hline 7 & Magnesium chloride & 741.2 \\
\hline 8 & Magnesium sulfate $\left(\mathrm{MgSO}_{4}\right)$ (anhydride) & 416.8 \\
\hline 9 & Potassium bromide & 10.1 \\
\hline 10 & Potassium chloride $(\mathrm{KCl})$ & 109.1 \\
\hline & Sodium bicarbonate $\left(\mathrm{NaHCO}_{3}\right)$ & 240.1 \\
\hline 12 & Sodium chloride $(\mathrm{NaCl})$ & 7123.5 \\
\hline 13 & Sodium fluoride & 0.3 \\
\hline & Sodium phosphate monobasic $\left(\mathrm{NaH}_{2} \mathrm{PO}_{4}-\mathrm{H}_{2} \mathrm{O}\right)$ & 14.0 \\
\hline & Sodium silicate & 0.5 \\
\hline & Sodium sulfite & 200.0 \\
\hline 17 & trontium chloride & 4.3 \\
\hline \multicolumn{3}{|c|}{ Other components } \\
\hline & D-glucose (dextrose) & 15600.0 \\
\hline 19 & Proteose peptone no. 3 & 8128.1 \\
\hline 20 & Pancreatic digest of casein & 7500.0 \\
\hline 21 & Soy peptone & 5000.0 \\
\hline \multicolumn{3}{|c|}{ Amino acids } \\
\hline 22 & Glycine & 0.8 \\
\hline 23 & L-alanine & 0.9 \\
\hline 24 & L-arginine & 12.6 \\
\hline 25 & L-asparagine- $\mathrm{H}_{2} \mathrm{O}$ & 1.3 \\
\hline 26 & L-aspartic acid & 1.3 \\
\hline 27 & L-cystine $2 \mathrm{HCl}$ & 1703.1 \\
\hline 28 & L-glutamic acid & 1.5 \\
\hline 29 & L-histidine hydrochloride- $\mathrm{H}_{2} \mathrm{O}$ & 4.2 \\
\hline 30 & L-isoleucine & 5.2 \\
\hline 31 & L-leucine & 5.2 \\
\hline 32 & L-lysine & 7.3 \\
\hline 33 & L-methionine & 1.5 \\
\hline 34 & L-phenylalanine & 3.2 \\
\hline 35 & L-proline & 1.2 \\
\hline 36 & L-serine & 1.1 \\
\hline 37 & L-threonine & 4.8 \\
\hline 38 & L-tryptophan & 1.0 \\
\hline 39 & L-tyrosine disodium salt dihydrate & 5.2 \\
\hline 40 & L-valine & 4.6 \\
\hline \multicolumn{3}{|c|}{ Vitamins } \\
\hline 41 & Choline chloride & 0.1 \\
\hline 42 & D-calcium pantothenate & 0.1 \\
\hline 43 & Folic acid & 0.1 \\
\hline 44 & Niacinamide & 0.1 \\
\hline 45 & Pyridoxal hydrochloride & 0.1 \\
\hline 46 & Riboflavin & 0.0 \\
\hline 47 & Thiamine hydrochloride & 0.1 \\
\hline 48 & i-inositol & 0.2 \\
\hline 49 & Yeast extract & 325.6 \\
\hline 50 & FBS cell culture Gibco ${ }^{\circledR}$ & $100 \mathrm{ml}$ \\
\hline
\end{tabular}

